\title{
Glutamine Synthetase of Streptomyces cattleya: Purification and Regulation of Synthesis
}

\author{
By PHILIP S. PARESS AND STANLEY L. STREICHER* \\ Merck Sharp and Dohme Research Laboratories, Rahway, New Jersey 07065, USA
}

(Received 31 December 1984 ; revised 2 April 1985)

Glutamine synthetase (GS; EC 6.3.1 .2) from Streptomyces cattleya was purified using a single affinity-gel chromatography step, and some of its properties were determined. Levels of GS in $S$. cattleya cells varied by a factor of 8 depending upon the source of nitrogen in the growth medium. Of 24 nitrogen sources examined only glutamine or $\mathrm{NH}_{4} \mathrm{Cl}$ utilization resulted in very low GS activity. Addition of $\mathrm{NH}_{4} \mathrm{Cl}$ to a culture with high $\mathrm{GS}$ levels appeared to stop further synthesis and resulted in a progressive decrease in the specific activity of the enzyme. The GS inhibitor methionine sulphoximine (MSX) inhibited GS activity but had no effect on exponentially growing cells. The presence of MSX either lengthened or shortened the period between spore inoculation and initiation of exponential growth, depending on the source of nitrogen. In glutamine minimal medium MSX produced earlier and more efficient spore germination while in glutamate or nitrate minimal medium germination was delayed by its presence.

\section{INTRODUCTION}

Streptomyces species produce many medically important antibiotics, but the physiological parameters that regulate their production are poorly understood. We are interested in the regulation of the synthesis of thienamycin, the novel $\beta$-lactam produced by Streptomyces cattleya (Kahan et al., 1979), and have begun to investigate nitrogen metabolism in this organism. The activity of glutamine synthetase (GS; EC 6.3.1.2), a key enzyme of nitrogen metabolism, is regulated by adenylylation (Streicher \& Tyler, 1981) in $S$. cattleya as it is in enteric bacteria such as Escherichia coli (Ginsburg \& Stadtman, 1973). In this paper we describe a simple single step purification of $S$. cattleya GS and compare some of its properties with the GS from enteric and other bacteria. We also present data on the effect of growth conditions on the levels and adenylylation state of $S$. cattleya GS.

\section{METHODS}

Bacterial strains, media and cell growth. Streptomyces cattleya strain MA4297, the original soil isolate (Kahan et al., 1979), was grown in minimal medium containing (per litre): $1.75 \mathrm{~g} \mathrm{~K}_{2} \mathrm{HPO}_{4}, 0.5 \mathrm{~g} \mathrm{NaCl}, 19.5 \mathrm{~g} \mathrm{MES}$, $0.1 \mathrm{~g} \mathrm{FeSO}_{4} .7 \mathrm{H}_{2} \mathrm{O}, 0.1 \mathrm{~g} \mathrm{CoCl}_{2} .6 \mathrm{H}_{2} \mathrm{O}$, and $0.1 \mathrm{~g} \mathrm{ZnSO}_{4} .7 \mathrm{H}_{2} \mathrm{O}$. The $\mathrm{pH}$ was adjusted to 6.5 with $\mathrm{NaOH}$. Glucose $(1 \%)$ was added as a carbon and energy source, and $20 \mathrm{~mm}$-monosodium glutamate as a nitrogen source, except where noted.

E. coli strains EG47 (Goldberg et al., 1974) and ET8002 (ET8000 carrying the glnA202 allele; MacNeil $e$ t al., 1982) were grown in minimal medium containing (per litre): $4.5 \mathrm{~g} \mathrm{KH}_{2} \mathrm{PO}_{4}, 10.5 \mathrm{~g} \mathrm{~K}_{2} \mathrm{HPO}_{4}$, $0 \cdot 16 \mathrm{~g} \mathrm{MgSO}_{4} .7 \mathrm{H}_{2} \mathrm{O}$, supplemented with $0.4 \%$ glucose and $0.2 \%$ aspartic acid. For growth on plates, the appropriate medium was solidified by the addition of $1.5 \%(\mathrm{w} / \mathrm{v})$ agar.

$S$. cattleya cultures were inoculated with either spores or vegetative cells and were incubated at $37^{\circ} \mathrm{C}$ with shaking ( 220 r.p.m.). Growth was followed by monitoring increases in optical density with a Klett-Summerson

Abbreviations: GS, glutamine synthetase; MSX, methionine sulphoximine. 
colorimeter (American Scientific Products, Edison, NJ, USA) with a no. 42 filter. The optical density for this filamentous bacterium was directly proportional to other parameters of cell growth such as cell dry weight, protein content and packed cell volume. Cells were harvested by centrifugation at the indicated times, washed once with $0.85 \% \mathrm{NaCl}$, and stored at $-80^{\circ} \mathrm{C}$. E. coli cells were grown and harvested as previously described (Streicher $e$ t al., 1976).

Preparation of crude extracts. Frozen cells were resuspended in 2 vols (w/v) buffer I $(20 \mathrm{mM}$-imidazole. $\mathrm{HCl}$, pH 7.5, $1 \mathrm{mM}-\mathrm{MnCl}_{2}$ ), and lysed by sonic oscillation (Heat Systems Ultrasonics, 38 East Mall, Plainview, Long Island, NY, USA) for $20 \mathrm{~s}$, unpulsed, at the maximum microtip power in an ice/salt water bath. The lysate was centrifuged for $40 \mathrm{~min}$ at $20000 \mathrm{~g}$ in a Sorvall RC-5B centrifuge with an SS-34 rotor. The supernatant fraction was removed and stored at $-80^{\circ} \mathrm{C}$.

Purification of $G S$. All purification steps were done at $4{ }^{\circ} \mathrm{C}$.

Step 1. The crude extract was dialysed against 500 vols buffer II (buffer I adjusted to $\mathrm{pH} 6 \cdot 3$ ) for $6 \mathrm{~h}$ with two buffer changes.

Step 2. Affi-gel Blue (Bio-Rad) was washed and equilibrated with buffer II. The dialysed crude extract was added to the gel slurry (10 to $40 \mathrm{GS}$ units per $\mathrm{ml}$ of gel) and mixed overnight on a rotating wheel.

Step 3. The equilibrated gel slurry was poured into a column $(3 \times 18 \mathrm{~cm})$ and washed with one bed volume of buffer II. Non-specifically bound proteins were eluted with buffer II containing $1 \mathrm{M}-\mathrm{NaCl}$ until the $A_{280}$ of the eluate returned to the initial baseline reading. The column was next washed with buffer II until all the $\mathrm{NaCl}$ was removed, as determined by conductivity measurements. GS was eluted with buffer I containing 5 mM-ADP, and collected in $10 \mathrm{ml}$ fractions.

Step 4. Fractions containing GS activity were pooled and concentrated using an Amicon ultrafiltration cell with a UM-20 membrane filter. Enzyme preparations were stored at $0^{\circ} \mathrm{C}$ or at $-80^{\circ} \mathrm{C}$. Purified GS was stable for more than three months under both storage conditions. GS from $E$. coli and Klebsiella aerogenes was purified as described previously (Streicher \& Tyler, 1980).

GS assays. $\gamma$-Glutamyl transferase activity of GS was determined as previously described (Bender et al., 1977; Streicher \& Tyler, 1981), except that the $S$. cattleya enzyme was assayed at $\mathrm{pH} \mathrm{6.9}$, its $\mathrm{pH}$ optimum. The adenylylation state of $S$. cattleya GS was estimated by comparing the transferase activity before and after incubation with snake venom phosphodiesterase (SVPDE; Boehringer-Mannheim), as previously described (Streicher \& Tyler, 1981). There is no isoactivity $\mathrm{pH}$ for adenylylated and unadenylylated $S$. cattleya GS as is found for other bacterial GS (Bender et al., 1977; Ginsburg \& Stadtman, 1973). Whole cell transferase activity was determined as previously described (Pahel et al., 1978; Streicher \& Tyler, 1981). One unit of GS produces $1 \mu \mathrm{mol} \gamma-$ glutamyl hydroxamate $\min ^{-1}$ (mg protein) ${ }^{-1}$.

In vitro adenylylation. Adenylylation of GS in crude extracts was done as described previously (Streicher \& Tyler, 1981).

Gel electrophoresis. SDS-PAGE was done as previously described (Bender \& Streicher, 1979).

Peptide mapping. Peptide mapping by limited proteolysis was done according to the method of Cleveland et al. (1977) using trypsin, chymotrypsin and Staphylococcus aureus V8 protease (all obtained from Miles Laboratories, Elkhart, Ind., USA).

Protein determination. Protein concentration was determined by either the Lowry method or the Bio-Rad dyebinding protein assay, with bovine serum albumin as the standard. Both assays gave identical results for crude extracts and purified enzyme preparations.

\section{RESULTS}

\section{Purification of S. cattleya GS}

GS was easily purified using an essentially single step affinity-gel chromatography procedure. SDS-PAGE showed an enzyme preparation $95-98 \%$ pure that contained a polypeptide with a molecular weight of 55000 (Table 1, Fig. 1). This procedure also gave high yields of purified enzyme from E. coli. Affi-gel Blue (Bio-Rad) had a significantly greater binding capacity for GS, and its use resulted in higher yields and enzymes of greater purity, than did Blue-Sepharose CL6B (Pharmacia) which utilizes the same affinity ligand. GS binding to the ligand was $\mathrm{pH}$ dependent, the greatest binding occurring at pH 6.3. Two other relatively simple purification methods, differential centrifugation and polyethylene glycol precipitation, which were described previously (Streicher \& Tyler, 1980), could not be used to purify $S$. cattleya GS.

Since GS could be specifically eluted from the affinity-gel with ADP, the ability of this procedure to purify adenylylated GS, which has an AMP moiety covalently bound to the protein, was investigated. We found that adenylylated GS could not be efficiently purified by our method. When GS in a crude extract was adenylylated, about $73 \%$ of the enzyme did not 


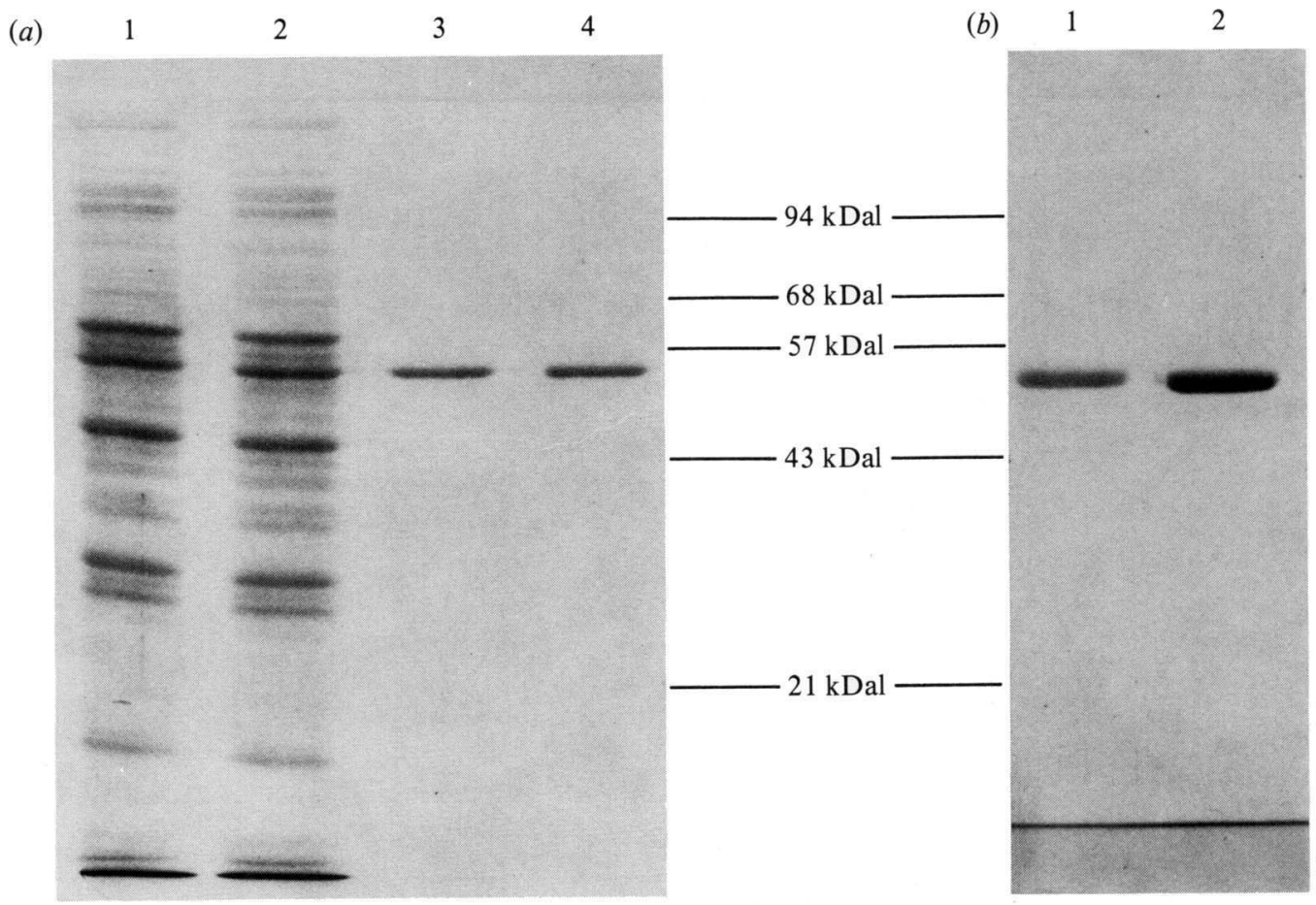

Fig. 1. (a) $10 \%$ SDS-PAGE of S. cattleya GS at each step of purification. Lane 1, crude extract; lane 2, dialysed crude extract; lane 3, Affi-gel Blue ADP eluate; lane 4, Amicon concentrate. All lanes contained 0.45 units GS activity. Molecular weight markers were phosphorylase B, $94 \mathrm{kDal}$; bovine serum albumin, $68 \mathrm{kDal}$; pyruvate kinase, $57 \mathrm{kDal}$; ovalbumin, $43 \mathrm{kDal}$; and soybean trypsin inhibitor, $21 \mathrm{kDal}$. (b) Comparison of purified GS from $S$. cattleya and $E$. coli. Lane 1, 0.23 unit E. coli GS; lane 2, 1.0 unit $S$. cattleya GS.

bind to the affinity-gel and was detected in the column run-through and washes. This is in contrast to the unadenylylated control extract where less than $5 \%$ of the GS activity eluted nonspecifically.

\section{Some properties of $S$. cattleya $G S$}

$S$. cattleya GS required $\mathrm{Mn}^{2+}$ for stability in crude extracts and purified enzyme preparations. Extracts prepared without $\mathrm{MnCl}_{2}$ lost more than $60 \%$ of their GS activity within $24 \mathrm{~h} . \mathrm{MgCl}_{2}$ could not substitute for $\mathrm{MnCl}_{2}$ to prevent loss of GS activity.

Electron microscopy of purified $S$. cattleya GS showed a dodecameric structure (data not shown) similar to that of the enzyme from $E$. coli and Bacillus subtilis and B. stearothermophilus (Valentine et al., 1968; Deuel et al., 1970; Wedler \& Hoffman, 1974). Amino acid analysis of $S$. cattleya GS revealed a composition similar to the enzyme from these other organisms (data not shown). Peptide maps generated by partial digestion using the proteolytic enzymes trypsin, chymotrypsin or $S$. aureus V8 protease revealed distinct differences between the GS from $S$. cattleya and that from two Gram-negative bacteria, E. coli and Klebsiella aerogenes (Fig. 2).

GS from both $S$. cattleya and $E$. coli could be adenylylated in vivo and in vitro under the same conditions, but the adenylylation system of one organism was incapable of modifying the GS of the other. Crude extracts were prepared from a $g \ln A E$. coli strain and $S$. cattleya cells grown in glutamine-supplemented minimal medium to ensure that each contained little or no endogenous GS. Each extract catalysed the adenylylation of purified homologous GS, but not that from the other strain, when incubated under a variety of conditions. 


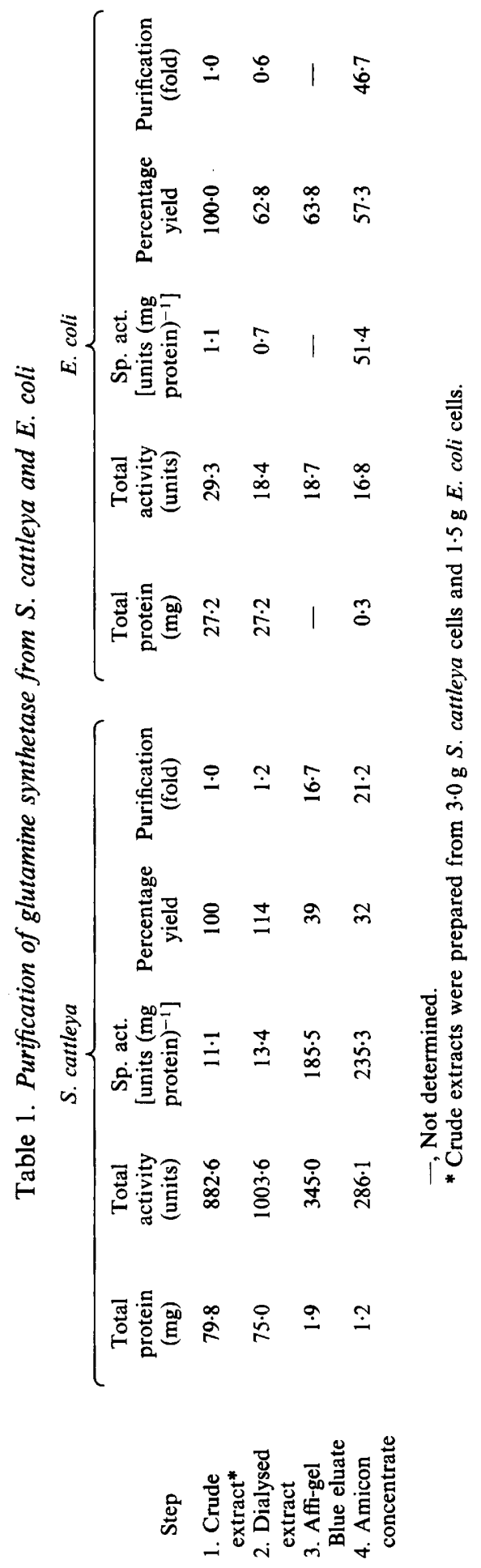




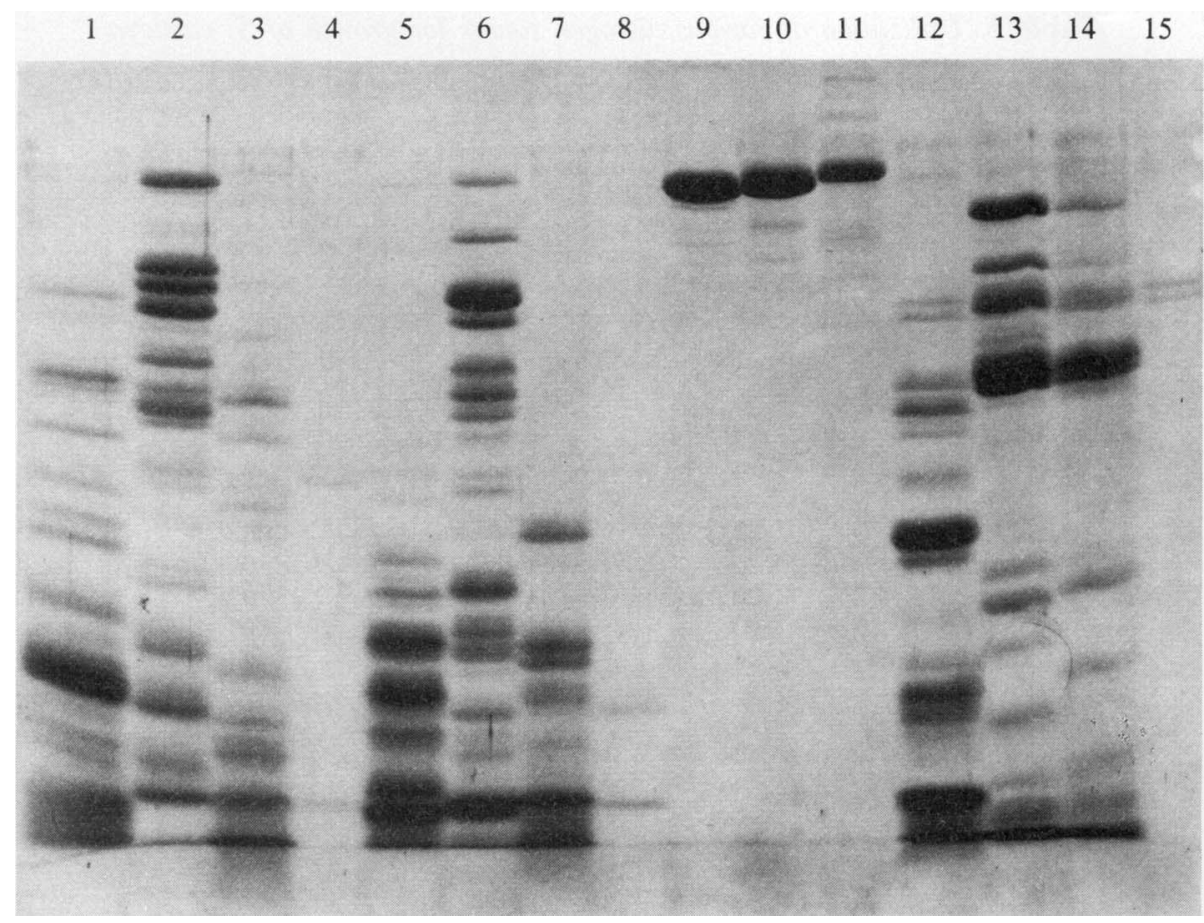

Fig. 2. Peptide map of GS from $S$. cattleya, E. coli and Klebsiella aerogenes. Purified enzyme $(50 \mu \mathrm{g})$ from each organism was partially digested with trypsin, chymotrypsin or $S$. aureus V8 protease $(2.5 \mu \mathrm{g}$ each) and electrophoresed in a 15\% SDS-polyacrylamide gel. Lanes 1-3, trypsin digestion of GS from $S$. cattleya (S.c.), E. coli (E.c.) and $K$. aerogenes (K.a.). Lane 4, trypsin (2.5 $\mu$ g). Lanes 5-7, chymotrypsin digestion of GS from S.c., E.c. and K.a. Lane 8, chymotrypsin $(2.5 \mu \mathrm{g})$. Lanes 9-11, $15 \mu \mathrm{g}$ each of undigested GS from S.c., E.c. and K.a. Lanes 12-14, S. aureus V8 protease digestion of GS from S.c., E.c. and K.a. Lane $15, S$. aureus V8 protease $(2 \cdot 5 \mu \mathrm{g})$.

\section{Nitrogen source utilization and GS regulation}

$S$. cattleya is able to utilize a variety of compounds as its sole source of nitrogen (Table 2). All but four of the common amino acids supported growth on solid medium when carbon and energy were supplied by either glucose or glycerol. Eight amino acids served additionally as sources of carbon and energy. Identical growth responses were obtained with either spore or vegetative cell inocula. GS activity assayed in crude extracts of cells grown in media containing different nitrogen sources varied greatly but did not correlate with the growth rate. This was strikingly demonstrated in liquid medium where, despite similar growth rates (generation times of 120 min and $100 \mathrm{~min}$ respectively), cells grown on glutamate had six to eightfold higher GS activity (8.6 units per mg protein) than cells grown on $\mathrm{NH}_{4} \mathrm{Cl}$ or glutamine (1.5 units per $\mathrm{mg}$ protein and 1.0 units per mg protein respectively). Conversely, cells grown on either glutamate or nitrate had comparable GS activity ( 8.6 and 7.7 units per $\mathrm{mg}$ protein respectively) but markedly different growth rates (generation times of $120 \mathrm{~min}$ and $300 \mathrm{~min}$ respectively). The differences in GS activity were due to changes in the amounts of GS protein present in the various cells, and not to the relative degree of adenylylation. The highest level of adenylylation found in growing cells was only $16 \%\left(\mathrm{NH}_{4} \mathrm{Cl}+\right.$ glutamate as nitrogen source). The phase of cell growth, from early to late exponential phase did not affect the specific activity of GS, or the ability of cell extracts to catalyse adenylylation.

We have previously shown that the addition of $\mathrm{NH}_{4} \mathrm{Cl}$ to cultures containing high GS levels caused a rapid loss of activity due to adenylylation (Streicher \& Tyler, 1981; Wax et al., 1982). The specific activity of GS, after in vitro deadenylylation by SVPDE treatment, in such a shocked culture progressively decreased: $6.5 \mathrm{~h}$ after $\mathrm{NH}_{4} \mathrm{Cl}$ addition it was approximately equal to that found in cultures grown continuously in $\mathrm{NH}_{4} \mathrm{Cl}$-containing medium. The total amount of 
Table 2. Utilization of various nitrogen soures for growth of $S$. cattleya

Minimal medium plates, with or without glucose $(0.8 \%)$, and supplemented with the indicated nitrogen source, were inoculated with either spores or washed vegetative cells, and incubated for $3 \mathrm{~d}$ at $37^{\circ} \mathrm{C}$.

\begin{tabular}{|c|c|c|c|c|}
\hline $\begin{array}{l}\text { Nitrogen } \\
\text { source }\end{array}$ & $\begin{array}{l}\text { Concn } \\
\text { (mM) }\end{array}$ & $\begin{array}{c}\text { Growth } \\
+ \text { glucose* }\end{array}$ & $\begin{array}{c}\text { GS } \\
\text { activity† }\end{array}$ & $\begin{array}{l}\text { Growth } \\
- \text { glucose }\end{array}$ \\
\hline Alanine & 20 & +++ & $+t+t$ & ++ \\
\hline Arginine & 20 & +++ & ++ & ++ \\
\hline Asparagine & 20 & +++ & +++ & + \\
\hline Aspartate & 20 & +++ & $++t$ & + \\
\hline Cysteine & 20 & 0 & ND & 0 \\
\hline Glutamine & 20 & ++++ & + & +++ \\
\hline Glutamate & 20 & ++++ & $+++t$ & +++ \\
\hline Glycine & 20 & +++ & ++++ & 0 \\
\hline Histidine & 20 & +++ & +++ & ++ \\
\hline Isoleucine & 20 & + & +++ & 0 \\
\hline Leucine & 20 & + & $+t+$ & 0 \\
\hline Lysine & 20 & +++ & ++++ & 0 \\
\hline Methionine & 20 & ++ & ++++ & 0 \\
\hline Phenylalanine & 4 & + & ++++ & 0 \\
\hline Proline & 20 & +++ & ++++ & ++ \\
\hline Serine & 20 & 0 & ND & 0 \\
\hline Threonine & 20 & 0 & ND & 0 \\
\hline Tryptophan & 4 & + & ++ & 0 \\
\hline Tyrosine & 4 & 0 & ND & 0 \\
\hline Valine & 20 & +++ & ++++ & 0 \\
\hline$\gamma$-Aminobutyrate & 20 & $+t+$ & ++++ & + \\
\hline Adenosine & 4 & $+t+$ & ++++ & $+t$ \\
\hline $\mathrm{NH}_{4} \mathrm{Cl}$ & 20 & +++ & + & ND \\
\hline $\mathrm{NaNO}_{3}$ & 20 & ++ & ND & ND \\
\hline
\end{tabular}

ND, Not determined.

* Growth was determined qualitatively comparing the diameters of isolated colonies and scored on a scale of ++++ (very good) to 0 (none).

† GS activities were determined qualitatively by the whole cell transferase assay. Colonies were picked from plates and incubated in assay mix in the wells of a microtitre dish for 30 to $60 \mathrm{~min}$ at $37^{\circ} \mathrm{C}$. Activity was evaluated on a scale of +++++ (high levels) to 0 (none detected), based upon the intensity of the brown colour produced by the assay.

GS protein in the ammonia-shocked culture appeared to remain constant, however, and the change in specific activity was probably due to cell growth with a concomitant increase in total cellular protein. Degradation of pre-formed GS did not appear to be occurring at any significant rate since incubation of crude extracts, even for long periods ( $24 \mathrm{~h}$ or longer) at $37^{\circ} \mathrm{C}$, did not result in loss of GS activity or changes in cellular proteins as analysed by 2-dimensional gel electrophoresis (data not shown).

\section{Effect of glutamine analogues on growth and GS activity}

Four compounds that would be expected to interfere with nitrogen metabolism were examined for their effect on $S$. cattleya. Three of the four ( $\gamma$-glutamyl hydroxamate, D-glutamine and $\beta$-2-thienylalanine) inhibited growth. Methionine sulphoximine (MSX), however, did not inhibit growth at any level tested. This is in contrast to its effect as a growth inhibitor in Gramnegative bacteria (Arp \& Zumft, 1983; Miller \& Brenchley, 1981; Pahel et al., 1978). The presence of MSX (10 mM) in glutamate-supplemented liquid medium delayed the initiation of exponential growth for $7 \mathrm{~h}$ when the culture was inoculated with spores. This delay also occurred when the source of nitrogen was $\mathrm{NH}_{4} \mathrm{Cl}$ or $\mathrm{NaNO}_{3}$. However, when glutamine was the source of nitrogen, exponential growth began significantly earlier than in the control cultures. The same effects upon the initiation of exponential growth were observed when MSX was added to cultures at any time up to $8 \mathrm{~h}$ post inoculation. The growth rate, once exponential growth started, 
was unchanged by the presence of MSX. These results suggest that MSX is affecting some stage of spore germination. The presence of MSX in glutamine medium resulted, after $8 \mathrm{~h}$, in a 100fold increase in the number of spores with germ tubes, compared to the untreated controls. At $12 \mathrm{~h}$ post-inoculation, about $90 \%$ of the spores in the MSX-treated culture had germinated, with evident mycelial branching, while in the untreated control only about $5 \%$ of the spores had germinated. These results are in contrast to those from glutamate-grown cultures where, after $12 \mathrm{~h}$, the treated one had about $5 \%$ spore germination, and the untreated control had about $50 \%$ spore germination with little mycelial branching.

The addition of MSX to exponentially growing cells caused a significant decrease in GS activity which, unlike the decrease caused by addition of $\mathrm{NH}_{4} \mathrm{Cl}$ or glutamine, could not be recovered by incubation of crude extracts with SVPDE. The low GS activity was not due to inhibition of the transferase assay by free unreacted MSX in the crude extracts. When a crude extract of MSX-treated cells was mixed with a crude extract from untreated cells, the specific activity of GS was the average of the two extracts.

\section{DISCUSSION}

We purified GS using a modification of an affinity-gel chromatography procedure described by Lepo et al. (1979). In our experience neither the second affinity-gel column nor the ion exchange column they used was required to obtain nearly homogeneous enzyme preparations from $S$. cattleya or $E$. coli. Adenylylated GS from neither $S$. cattleya nor $E$. coli bound to the affinity matrix under our conditions and therefore could not be purified.

Purified S. cattleya GS has a native dodecameric structure similar to that of all bacterial GS (Ginsburg \& Stadtman, 1973). Its subunit molecular weight is 55000 , the same as $E$. coli GS. The peptide mapping experiment revealed distinct differences between $S$. cattleya GS and that from the enterics $E$. coli and $K$. aerogenes. It was somewhat surprising that the two enteric enzymes appear by this analysis to be so different since they can substitute for one another for in vivo and in vitro adenylylation/deadenylylation, and that normal growth and regulation occur in interspecies hybrid strains (Streicher et al., 1976; Tyler, 1978). S. cattleya GS is, however, different enough that, in vitro at least, no heterologous adenylylation activity was observed.

Under balanced growth conditions the levels of GS activity in cells grown on different nitrogen sources can vary by a factor of 8 . These differences appear to reflect changes in the levels of enzyme synthesis and not adenylylation. Adenylylation levels did not exceed $16 \%$ unless an ammonia or glutamine shock occurred. The long term result of ammonia shock on a glutamate culture was a progressive decrease of GS specific activity to the low level found in ammonia + glutamate grown cells, probably due to the maintenance of the pre-shock GS level as cells continued to grow and increase their protein content. Although continued GS synthesis coupled with an increased rate of GS degradation could have caused the specific activity to decrease, this was probably not occurring since GS activity in crude extracts was stable in the presence of $\mathrm{Mn}^{2+}$ and proteolytic activity was not observed. It is most probable that long term regulation of GS levels occurs by altering expression of the structural gene $(g \ln A)$.

Methionine sulphoximine (MSX) had a profound effect on spore germination, either accelerating or delaying it, depending on the source of nitrogen. After germination MSX did not have any effect on growth, even at high concentrations. The addition of MSX to exponentially growing cells caused GS activity to drop 10- to 100-fold. MSX may be inactivating other enzymes in addition to GS or may be causing the derepression of some that have roles in early spore germination. In other bacteria, MSX addition, besides inactivating GS, resulted in elevated levels of other enzymes (Garber et al., 1980; Smith et al., 1981). In some of the initial studies of the effect of MSX on growth in solid media we noticed that the formation of aerial mycelia was enhanced and that sporulation occurred earlier. This suggests that some stages of differentiation leading to spore formation are also perturbed by MSX. It is not clear whether the effects on germination and sporulation are related. 


\section{REFERENCES}

ARP, D. P. \& ZUMFT, W. G. (1983). L-Methionine-SRsulfoximine as a probe for the role of glutamine synthetase in nitrogenase switch-off by ammonia in Rhodopseudomonas palustris. Archives of Microbiology 134, 17-22.

Bender, R. A. \& Streicher, S. L. (1979). Glutamine synthetase regulation, adenylylation state and strain specificity analyzed by polyacrylamide gel electrophoresis. Journal of Bacteriology 137, 1000-1007.

Bender, R. A., JANSSEN, K. A., Resnick, A. D. BlumenberG, M., FoOR, F. \& MAGASANIK, B. (1977). Biochemical parameters of glutamine synthetase from Klebsiella aerogenes. Journal of Bacteriology 129, 1001-1009.

Cleveland, D. W., Fischer, S. G., Kirschner, M. W. \& Laemmli, U. K. (1977). Peptide mapping by limited proteolysis in sodium dodecyl sulfate and analysis by gel electrophoresis. Journal of Biological Chemistry 252, 1102-1106.

Deuel, T. F., Ginsburg, A., Yeh, J., Shelton, E. \& StaDTMan, E. R. (1970). Bacillus subtilis glutamine synthetase. Purification and physical characterization. Journal of Biological Chemistry 245, 5195-5205.

GARBER, B. B., Jochimsen, B. U. \& GoTs, J. S. (1980). Glutamine and related analogs regulate guanosine monophosphate reductase in Salmonella typhimurium. Journal of Bacteriology 143, 105-111.

Ginsburg, A. \& StadtMan, E. R. (1973). Regulation of glutamine synthetase in Escherichia coli. In The Enzymes of Glutamine Metabolism, pp. 9-44. Edited by $\mathbf{S}$. Prusiner \& E. R. Stadtman. London: Academic Press.

Goldberg, R. B., Bender, R. A. \& Streicher, S. L. (1974). Direct selection for Pl-sensitive mutants of enteric bacteria. Journal of Bacteriology 118, 810814.

Kahan, J. S., Kahan, F. M., Goegelman, R., Currie, S. A., Jackson, M., Stapley, E. O. Miller, T. W., Miller, A. K., Hendlin, D. Mochales, S., Hernandez, S., Woodruf, H. B. \& BIRNBaUM, J. (1979). Thienamycin, a new $\beta$-lactam antibiotic. I. Discovery, taxonomy, isolation and physical properties. Journal of Antibiotics 32, 1-12.

LePo, J. E., Stacey, G., Wyss, O. \& TABita, F. R. (1979). The purification of glutamine synthetase from Azotobacter and other prokaryotes by blue
Sepharose Chromatography. Biochimica et biophysica acta 568, 428-436.

MacNeil, T., MacNeil, D. \& Tyler, B. (1982). Finestructure deletion map and complementation analysis of the $g \ln A-g \ln L-g \ln G$ region in Escherichia coli. Journal of Bacteriology 150, 1302-1313.

MilleR, E. S. \& BRENCHLEY, J. E. (1981). LMethionine-SR sulfoximine resistant glutamine synthetase mutants from Salmonella typhimurium. Journal of Biological Chemistry 256, 11307-11312.

Pahel, G., Zelenetz, A. D. \& Tyler, B. M. (1978). glt $B$ gene and regulation of nitrogen metabolism by glutamine synthetase EC 6.3.1.2 in Escherichia coli. Journal of Bacteriology 133, 139-148.

Smith, C. J., Hespell, R. B. \& BRyant, M. P. (1981). Regulation of urease and ammonia assimilatory enzymes in Selenomonas ruminantium. Applied and Environmental Microbiology 42, 89-96.

STREICHER, S. \& TYLER, B. (1981). Regulation of glutamine synthetase activity by adenylylation in the gram-positive bacterium Streptomyces cattleya. Proceedings of the National Academy of Sciences of the United States of America 78, 229-233.

STReicher, S. L. \& TYLER, B. (1980). Purification of glutamine synthetase from a variety of bacteria. Journal of Bacteriology 142, 69-78.

Streicher, S. L., Deleo, A. B. \& Magasanik, B. (1976). Regulation of enzyme formation in Klebsiella aerogenes by episomal glutamine synthetase of Escherichia coli. Journal of Bacteriology 120, 184-192.

TYLER, B. (1978). Regulation of the assimilation of nitrogen compounds. Annual Review of Biochemistry 47, 1127-1162.

Valentine, R. C., Shapiro, B. M. \& Stadtman, E. R. (1968). Regulation of glutamine synthetase XII. Electron microscopy of the enzyme from Escherichia coli. Biochemistry 7, 2143-2152.

WAX, R., SNYDER, L. \& KAPLAN, L. (1982). Inactivation of glutamine synthetase by ammonia shock in the gram-positive bacterium Streptomyces cattleya. Applied and Environmental Microbiology 44, 10041006.

Wedler, F. C. \& HofFManN, F. M. (1974). Glutamine synthetase of Bacillus stearothermophilus. I. Purification and basic properties. Biochemistry 13, 3207 3214. 